\title{
Effects of feeding corn naturally contaminated with aflatoxin on growth performance, apparent ileal digestibility, serum hormones levels and gene expression of $\mathrm{Na}^{+}, \mathrm{K}^{+}$-ATPase in ducklings
}

\author{
Farzana Abbasi ${ }^{1}$, Jingbo Liu ${ }^{1,2}$, Hongfu Zhang ${ }^{2}$, Xiaoyun Shen ${ }^{1,3}$, and Xuegang Luo ${ }^{1, *}$
}

\section{* Corresponding Author: Xuegang Luo Tel: +86-0816-6089521, Fax: +86-0816-6089521 E-mail: luoxgswust@163.com}

'School of Life Science and Engineering, Southwest University of Science and Technology, Mianyang 621010, China

${ }^{2}$ State Key Laboratory of Animal Nutrition, Institute of Animal Sciences, Chinese Academy of Agricultural Sciences, Beijing 100193, China

${ }^{3}$ State Engineering Technology Institute for Karst Desertification Control, Guizhou Normal University, Guiyang 550001, China

\section{ORCID}

Farzana Abbasi

https://orcid.org/0000-0003-2552-6191 Jingbo Liu

https://orcid.org/0000-0001-5409-4426 Hongfu Zhang

https://orcid.org/0000-0003-0177-8773

Xiaoyun Shen

https://orcid.org/0000-0002-2170-8425

Xuegang Luo

https://orcid.org/0000-0002-9132-7089

Submitted May 16, 2017; Revised Jul 14, 2017; Accepted Aug 3, 2017
Objective: A 14-d trial was conducted to determine the effects of feeding corn naturally contaminated with aflatoxin $\mathrm{B}_{1}\left(\mathrm{AFB}_{1}\right)$ on growth performance, apparent ileal digestibility, serum hormones levels and gene expression of $\mathrm{Na}^{+}, \mathrm{K}^{+}$-ATPase in ducklings.

Methods: A total of 704 ducklings were blocked on the basis of sex and body weight (BW), and then allocated randomly to one of the following two treatments: i) $\mathrm{CON}$, basal diet and ii) $\mathrm{AFB}_{1}$, diets with $100 \%$ of normal corn replaced with $\mathrm{AFB}_{1}$ contaminated corn. There were 22 pens per treatment and 16 birds per pen. The concentration of $\mathrm{AFB}_{1}$ was 195.4 and $124.35 \mu \mathrm{g} / \mathrm{kg}$ in the contaminated corn and $\mathrm{AFB}_{1}$ diet, respectively.

Results: The $\mathrm{AFB}_{1}$ decreased average daily gain, average daily feed intake, $\mathrm{d} 7 \mathrm{BW}$, final $\mathrm{BW}$ in the whole trial, and feed conversion ratio (FCR) during $\mathrm{d} 8$ to 14 and $\mathrm{d} 1$ to 14 by $10 \%$ to $47 \%$ $(\mathrm{p}<0.05)$, while FCR during $\mathrm{d} 1$ to 7 was increased $(\mathrm{p}<0.05)$. $\mathrm{AFB}_{1}$ did not affect mortality to $7 \mathrm{~d}$ of age, and then increased to $5.8 \%$ from 8 to $14 \mathrm{~d}$ of age $(\mathrm{p}<0.01)$. Apparent ileal gross energy digestibility was reduced by $\mathrm{AFB}_{1}$, whereas apparent ileal digestibility of dry matter, nitrogen, and amino acid was improved $(\mathrm{p}<0.01)$. Feeding $\mathrm{AFB}_{1}$ diets increased serum concentration of leptin and insulin-like growth factors-1 (IGF-1) $(\mathrm{p}<0.05)$, but had no effect on neuropeptide Y, ghrelin, cholecystokinin- 8 or insulin ( $\mathrm{p}>0.05)$. Dietary treatments did not influence relative expression of jejunal $\mathrm{Na}^{+}, \mathrm{K}^{+}$-ATPase gene ( $\left.\mathrm{p}>0.05\right)$.

Conclusion: Taken together, feeding corn naturally contaminated with $\mathrm{AFB}_{1}$ reduced growth performance, improved apparent ileal digestibility, and affected serum leptin and IGF-1 in ducklings from $\mathrm{d} 1$ to 14 .

Keywords: Aflatoxin $\mathrm{B}_{1}$; Ducklings; Leptin; Nutrient Digestibility; Performance

\section{INTRODUCTION}

Aflatoxin $\mathrm{B}_{1}\left(\mathrm{AFB}_{1}\right)$ produced by Aspergillus species is the most toxic of aflatoxins (AF) subgroup [1]. China has the largest number of ducks on the earth [2]. Ducks are the most susceptible species to $\mathrm{AFB}_{1}$ among all the poultry species because they cannot efficiently metabolize $\mathrm{AF}$ [3-4]. Corn, as the major energy source, accounts for more than $50 \%$ of duck feed in China. Furthermore, it was reported that the corn was extremely susceptible to the $\mathrm{ABF}_{1}$ with the incidence rate being above $82 \%$ in China [5].

The effects of $\mathrm{ABF}_{1}$ on growth performance, hepatic functions, immunity, intestinal morphology and blood profiles have been already documented in ducks [6-9]. Feeding naturally $\mathrm{AFB}_{1}$ contaminated diets $(120.02 \mu \mathrm{g} / \mathrm{kg}$ in the starter diet and $153.12 \mu \mathrm{g} / \mathrm{kg}$ in the grower diet) compromised growth performance and intestinal morphology, changed digestive physiology and development in ducks [10]. A recent study explored how dietary crude protein (CP) concentration and semi-pure $\mathrm{AFB}_{1}$ affects the nutrient digestion and absorption in 14-d Pekin ducks, in 


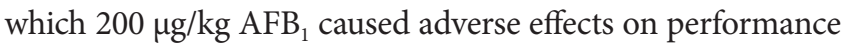
primarily through decreased feed intake and the influence on nutrient digestion processes (jejunum morphology, digestive enzyme activity, and apparent energy digestibility) [11]. Higher dietary $\mathrm{CP}$ can increase growth performance regardless of $\mathrm{AFB}_{1}$ without interactive effects [11]. Recent studies revealed the impact of $\mathrm{AFB}_{1}$ on the gastro-intestinal tract $[10,11]$, which was supported by a study that observed the biotransformation of $\mathrm{AFB}_{1}$ to the toxic $\mathrm{AFB}_{1}$-exo-8,9-epoxide (AFBO) also occurred in the intestinal tract [12]. $\mathrm{AFB}_{1}$ is known to be a potent inhibitor of protein synthesis $[13,14]$ because $\mathrm{AFBO}$, as its metabolite, may be able to interact with DNA and RNA in poultry [15].

Based on the above results, we hypothesized that the detrimental effects of $\mathrm{AFB}_{1}$ on ducks were correlated to nutrient absorption transporter and several hormones involved in ingestion and digestion. However, very limited information is available on serum hormones and gene expression of nutrient absorption carrier in ducks fed diets naturally contaminated with $\mathrm{AFB}_{1}$. Therefore, the objectives of the current study were to explore the effects of feeding corn naturally contaminated with $\mathrm{AFB}_{1}$ on growth performance, apparent ileal digestibility, serum hormones levels and gene expression of $\mathrm{Na}^{+}, \mathrm{K}^{+}$-ATPase in ducklings.

\section{MATERIALS AND METHODS}

\section{Analysis of dietary mycotoxins}

Dietary mycotoxins concentrations were measured by enzymelinked immunosorbent assay method (kits, Neogen Company, Lansing, MN, USA; Microplate Reader, Model 680, Bio-Rad, Hercules, CA, USA) according to the manufacturer's instructions. The detection limits of the assay kits were 2 to $200 \mu \mathrm{g} / \mathrm{kg}$ for $\mathrm{AFB}_{1}, 2$ to $25 \mu \mathrm{g} / \mathrm{kg}$ for ochratoxin, 0.025 to $0.25 \mu \mathrm{g} / \mathrm{kg}$ for T2 toxins, 1 to $6 \mu \mathrm{g} / \mathrm{kg}$ for fumonisins, 0.025 to $0.25 \mu \mathrm{g} / \mathrm{kg}$ for deoxynivalenol, and 0.02 to $0.5 \mu \mathrm{g} / \mathrm{kg}$ for zearalenone, respectively.

\section{Experimental design and duck husbandry}

The Animal Welfare Committee of Southwest University of Science and Technology approved the animal care protocol used for this experiment. A total of 704 one-d-old Cherry Valley ducklings with an average initial BW of 55.9 $\pm 0.2 \mathrm{~g}$ were weighed, tagged, and randomly allotted to 44 pens on the basis of sex and body weight. All ducklings were housed in an environmentally controlled room.

This 2-wk trial consisted of 2 treatments with 22 pens per treatment and 16 birds per pen ( 8 males and 8 females) in a randomized complete block design. Birds were fed from 1 to $14 \mathrm{~d}$ of age. All diets (Table 1) were formulated to meet or exceed the NRC [16] requirements for ducks, and the dietary treatments were control $(\mathrm{CON})$ and $100 \%$ contaminated corn. Diets were fed in pellet form and feed and water were provided ad libitum.

\section{Sampling and measurements}

Table 1. Diet composition (as-fed basis)

\begin{tabular}{|c|c|}
\hline Item & Starter ${ }^{1)}$ \\
\hline \multicolumn{2}{|l|}{ Ingredients (\%) } \\
\hline Corn & 59.05 \\
\hline Soybean meal (CP 46\%) & 30.60 \\
\hline Wheat flour & 5.00 \\
\hline Soybean oil & 0.70 \\
\hline Rice bran & 0.50 \\
\hline Calcium phosphate & 1.65 \\
\hline Limestone & 1.10 \\
\hline sodium chloride & 0.30 \\
\hline Choline chloride (50\%) & 0.10 \\
\hline DL-Met $(99 \%)$ & 0.18 \\
\hline L-Lys@HCl $(78 \%)$ & 0.07 \\
\hline $\mathrm{Cr}_{2} \mathrm{O}_{3}$ & 0.50 \\
\hline Vitamin premix $x^{2)}$ & 0.10 \\
\hline Trace mineral premix ${ }^{3)}$ & 0.15 \\
\hline \multicolumn{2}{|l|}{ Analytical composition } \\
\hline ME $(M J / k g)^{4)}$ & 12.14 \\
\hline Crude protein (\%) & 19.72 \\
\hline Lys (\%) & 1.10 \\
\hline $\mathrm{Ca}(\%)$ & 0.97 \\
\hline $\mathrm{P}(\%)$ & 0.63 \\
\hline \multicolumn{2}{|c|}{$\begin{array}{l}\mathrm{CP} \text {, crude protein; ME, metabolizable energy. } \\
\text { 1) Provided starter diets during wk } 1 \text { to } 2 \text {. } \\
\text { 2) Provided per kilogram of diet: vitamin } \mathrm{A}, 2,500 \mathrm{IU} \text {; vitamin } \mathrm{D}_{3}, 400 \mathrm{IU} \text {; vitamin } \mathrm{E}, 10 \\
\mathrm{IU} \text {; vitamin } \mathrm{K}_{3}, 0.5 \mathrm{mg} \text {; vitamin } \mathrm{B}_{1}, 2.0 \mathrm{mg} \text {; vitamin } \mathrm{B}_{6}, 2.5 \mathrm{mg} \text {; vitamin } \mathrm{B}_{12}, 0.02 \mathrm{mg} \text {; } \\
\text { nicotinic acid, } 55 \mathrm{mg} \text {; pantothenic acid, } 10 \mathrm{mg} \text {; folic acid, } 1.0 \mathrm{mg} \text {; and biotin, } 0.1 \mathrm{mg} \text {. } \\
\text { 3) Provided per kilogram of diet: } 60 \mathrm{mg} \mathrm{Fe}\left(\mathrm{FeSO}_{4} \cdot 7 \mathrm{H}_{2} \mathrm{O}\right) ; 8 \mathrm{mg} \mathrm{Cu}\left(\mathrm{CuSO}_{4} \cdot 5 \mathrm{H}_{2} \mathrm{O}\right) ; 60 \mathrm{mg} \\
\mathrm{Zn}\left(\mathrm{ZnSO}_{4} \cdot 7 \mathrm{H}_{2} \mathrm{O}\right) ; 50 \mathrm{mg} \mathrm{Mn}\left(\mathrm{MnSO}_{4} \cdot \mathrm{H}_{2} \mathrm{O}\right) ; 0.1 \mathrm{mg} \mathrm{Se}\left(\mathrm{Na}_{2} \mathrm{SeO}_{3} \cdot 5 \mathrm{H}_{2} \mathrm{O}\right) ; \text { and } 0.2 \mathrm{mg} \mathrm{I}(\mathrm{KI}) \text {. } \\
\text { 4) Calculated values. }\end{array}$} \\
\hline
\end{tabular}

The ducklings were weighed and feed intake was recorded on $\mathrm{d}$ 1,7 , and 14 , and average daily gain (ADG), average daily feed intake (ADFI), and feed conversion ratio (FCR) were calculated. Dead birds were weighed daily, and the mortality was recorded as it occurred.

At the end of the experiment, 8 ducklings ( 4 males and 4 females) were randomly selected from each pen and blood samples were collected from the jugular vein into a sterile syringe and stored at $4^{\circ} \mathrm{C}$. Samples were then centrifuged at $3,000 \times \mathrm{g}$ for 15 min and serum was separated. After blood collection, the same ducks were sacrificed by cervical dislocation. The lower $2 / 3$ ileal digesta was collected by flushing with reverse osmosis water for nitrogen $(\mathrm{N})$, gross energy $(\mathrm{GE})$, dry matter $(\mathrm{DM})$, ether extract (EE), chromium (Cr), and amino acid (AA) determination. A section of mid jejunum was gently scraped with a glass slide, and mucosa was frozen in liquid nitrogen, and stored at $-80^{\circ} \mathrm{C}$ for relative gene expression of $\mathrm{Na}^{+}, \mathrm{K}^{+}$-ATPase analysis.

All diets and ileal samples were analyzed for DM, N, EE, crude ash, calcium, and phosphorus according to AOAC $[17,18]$. $\mathrm{Cr}$ was analyzed via UV absorption spectrophotometry (Shimadzu UV-1201, Shimadzu, Kyoto, Japan) [18]. Energy was determined by measuring the heat of combustion in the samples using a Parr 6100 oxygen bomb calorimeter (Parr instrument Co., Moline, 
Table 2. Primer sequences of gene for $\mathrm{Na}^{+}, \mathrm{K}^{+}$-ATPase

\begin{tabular}{lll}
\hline Gene & Sequences of forward primer & Sequences of reverse primer \\
\hline $\mathrm{Na}^{+}, \mathrm{K}^{+}$-ATPase & CGTGGCATTGTTATTAGGAC & GTATTCAAGGATCAGCGAGA \\
\hline
\end{tabular}

IL, USA). Amino acid contents were determined, following acid hydrolysis with $6 \mathrm{~N} \mathrm{HCl}$ at $110^{\circ} \mathrm{C}$ for $24 \mathrm{~h}$, using an AA analyzer (Biochrom 20, Pharmacia Biotech, Cambridge, England). Before acid hydrolysis, Met and Cys were oxidized with formic acid. Tryptophan was determined after $\mathrm{NaOH}$ hydrolysis for $22 \mathrm{~h}$ at $110^{\circ} \mathrm{C}$

The serum neuropeptide Y (NPY), ghrelin, leptin, cholecystokinin-8 (CCK-8), insulin, insulin-like growth factors-1 (IGF-1) levels were analyzed by radioimmunoassay method using kits (Shanghai Yuanye Biotechnology Co. Ltd., shanghai, China) according to the manufacturer's instructions. Automatic radioimmunoassay $\gamma$ counter (H-7500, Hitachi, Tokyo, Japan) was used for determination.

Total RNA extraction, reverse transcription reaction and quantitative real-time polymerase chain reaction (PCR) of $\mathrm{Na}^{+}, \mathrm{K}^{+}$ATPase gene was determined as previously described [19]. Briefly, total RNA of tissues was extracted with RNAiso Reagent (TaKaRa, Kyoto, Japan) and reverse-transcribed with RT Reagents (TaKaRa, Japan) according to manufacturer's instructions. Quantitative real-time PCR was performed using 96-well iCycler iQTM RealTime PCR Detection System (Bio-Rad, USA). The gene-specific primers used are listed in Table 2 and purchased from TaKaRa (Japan). The PCR system consisted of $12.5 \mathrm{~mL}$ SYBR Green PCR Master Mix (TaKaRa, Japan), $2.0 \mathrm{~mL}$ of cDNA, $8.5 \mathrm{~mL}$ of PCRgrade water and $2.0 \mathrm{~mL}$ of primer pairs $(100 \mathrm{mM}$ forward and $100 \mathrm{mM}$ reverse) for a total volume of $25 \mathrm{~mL}$. All samples were assayed in triplicate. Cycling conditions were as follows: $94^{\circ} \mathrm{C}$ for $10 \mathrm{~s}$, and 40 cycles involving a combination of $94^{\circ} \mathrm{C}$ for $5 \mathrm{~s}$, $55.5^{\circ} \mathrm{C}$ for $20 \mathrm{~s}$ and $72^{\circ} \mathrm{C}$ for $15 \mathrm{~s}$. Relative gene expression to the house-keeping gene ( $\beta$-actin) was performed in order to correct for the variance in amounts of RNA input in the reactions. However, the relative gene expressions compared to the house-keeping gene were calculated [20]. The primer sequences of gene for $\mathrm{Na}^{+}$,
$\mathrm{K}^{+}$-ATPase are presented in Table 2.

\section{Statistical analysis}

Data were analyzed by analysis of variance using the T-test procedure of SAS (SAS Inst. Inc., Cary, NC, USA) with the pen being the experimental unit. Variability in the data was expressed as the standard error of means. Probability values less than 0.05 were considered significant.

\section{RESULTS}

\section{Mycotoxins levels of corn and diets}

Concentrations of various mycotoxins, as well as their regulatory guidance concentration, in corn and diets are presented in Table 3. The dietary $\mathrm{AFB}_{1}$ was 2.87 and $124.35 \mu \mathrm{g} / \mathrm{kg}$ for $\mathrm{CON}$ and $\mathrm{AFB}_{1}$, respectively. Only $\mathrm{AFB}_{1}$ exceeded the regulatory guidance concentration of Chinese National Standard (GB 13078-2001), while others did not exceed the regulatory limits of Chinese National Standard (GB 13078.2-2006, GB 13078.3-2007, and GB 216932008) and European Commission [21].

The GE and nutrient composition between normal corn and contaminated corn are presented in Table 4, which showed few differences.

\section{Growth performance}

From $\mathrm{d} 1$ to 7 , feeding $\mathrm{AFB}_{1}$ diets decreased $\mathrm{d} 7 \mathrm{BW}, \mathrm{ADG}$, and ADFI by $22 \%, 31 \%$, and $23 \%$, respectively $(\mathrm{p}<0.05)$, while FCR increased by $11 \%(\mathrm{p}<0.05)$ (Table 5). From $\mathrm{d} 8$ to 14 , birds fed $\mathrm{AFB}_{1}$ diets had lower ADG, ADFI, and FCR $(\mathrm{p}<0.05)$ with the reduction of $41 \%, 47 \%$, and $10 \%$, respectively. In the whole trial, the $\mathrm{AFB}_{1}$ reduced final $\mathrm{BW}, \mathrm{ADG}, \mathrm{ADFI}$, and FCR by $34 \%, 39 \%$, $43 \%$, and $8 \%(\mathrm{p}<0.05)$. Mortality was increased by $\mathrm{AFB}_{1}$ diets $(\mathrm{p}<0.01)$ from $\mathrm{d} 8$ to 14 and $\mathrm{d} 1$ to 14 .

Table 3. The concentration of mycotoxins in corn and diets

\begin{tabular}{|c|c|c|c|c|c|c|}
\hline \multirow{2}{*}{ Mycotoxins } & \multirow{2}{*}{ Normal corn } & \multirow{2}{*}{ Contaminated corn } & \multirow{2}{*}{$\mathrm{CON}^{11}$} & \multirow{2}{*}{$\mathrm{AFB}_{1}{ }^{1)}$} & \multicolumn{2}{|c|}{ Limits } \\
\hline & & & & & Corn & Complete diet ${ }^{2}$ \\
\hline $\mathrm{AFB}_{1}(\mu \mathrm{g} / \mathrm{kg})$ & 3.80 & 195.4 & 2.87 & 124.35 & $50.0^{3)}$ & 10.0 \\
\hline $\mathrm{OA}(\mu \mathrm{g} / \mathrm{kg})$ & 5.25 & 4.35 & 1.18 & 0.75 & $100^{3)}$ & 100 \\
\hline $\mathrm{T} 2$ (mg/kg) & 0.12 & 0.05 & 0.04 & 0.05 & - & 1.00 \\
\hline $\mathrm{FM}(\mathrm{mg} / \mathrm{kg})$ & 1.00 & 3.35 & 1.03 & 4.50 & $60.0^{4)}$ & $20.0^{4)}$ \\
\hline DON (mg/kg) & 0.45 & 0.24 & 0.50 & 0.45 & 5.00 & 1.00 \\
\hline ZEA (mg/kg) & 0.21 & 0.08 & 0.17 & 0.15 & $0.50^{3)}$ & 0.50 \\
\hline
\end{tabular}

$\mathrm{AFB}_{1}$, aflatoxin $\mathrm{B}_{1} ; \mathrm{OA}$, ochratoxin; $\mathrm{T2}$, T2 toxins; FM, fumonisins; DON, deoxynivalenol; ZEA, zearalenone.

1) CON, basal diet; AFB1, basal diet containing 100\% contaminated corn.

2) Chinese National Standard (GB) 13078-2001, GB 13078.2-2006, GB 13078.3-2007 and GB 21693-2008 of China (Beijing, China).

${ }^{3)}$ GB 13078-2001 and GB 13078.2-2006 of China.

4) European Commission [21]. 
Table 4. The GE and nutrient composition between normal corn and contaminated corn

\begin{tabular}{lcc}
\hline Items & Normal corn & Contaminated corn \\
\hline GE (MJ/kg) & 16.2 & 16.15 \\
DM (\%) & 86.94 & 86.79 \\
CP (\%) & 7.81 & 7.70 \\
Starch (\%) & 64.9 & 65.10 \\
Lys (\%) & 0.27 & 0.28 \\
Met+cys (\%) & 0.38 & 0.37 \\
Thr (\%) & 0.37 & 0.37
\end{tabular}

$\mathrm{GE}$, gross energy; $\mathrm{DM}$, dry matter; $\mathrm{CP}$, crude protein.

\section{Apparent ileal digestibility}

Apparent ileal digestibility of DM, N, and AA was increased ( $\mathrm{p}<$ 0.05 ) by $\mathrm{AFB}_{1}$ diets, whereas apparent ileal digestible energy digestibility was decreased $(\mathrm{p}<0.05)$ (Table 6$)$. No difference was observed in apparent ileal EE digestibility between treatments $(\mathrm{p}>0.05)$.

Serum hormones levels and relative expression of $\mathrm{Na}^{+}, \mathrm{K}^{+}$ATPase gene

Serum levels of leptin and IGF-1 was increased by $\mathrm{AFB}_{1}$ diets ( $\mathrm{p}<$ $0.05)$, while NPY, ghrelin, CCK-8 and insulin were not affected $(\mathrm{p}>0.05)$ (Table 7$)$. There was no difference $(\mathrm{p}>0.05)$ in relative expression of $\mathrm{Na}^{+}, \mathrm{K}^{+}$-ATPase between treatments (Table 8).

\section{DISCUSSION}

Table 5. Effects of feeding corn naturally contaminated with $\mathrm{AFB}_{1}$ on growth performance in ducklings ${ }^{11}$

\begin{tabular}{lcccc}
\hline Item & CON $^{2)}$ & AFB $_{1}^{2), 3)}$ & SEM & p-value \\
\hline Initial BW (g) & 55.98 & 55.82 & 0.25 & 0.30 \\
d 7 BW (g) & 217.9 & 169.16 & 4.06 & $<0.01$ \\
Final BW (g) & 661.06 & 433.73 & 9.68 & $<0.01$ \\
ADG (g) & & & & \\
d 1-7 & 23.10 & 15.83 & 2.06 & 0.03 \\
d 8-14 & 63.31 & 36.99 & 7.58 & 0.02 \\
d 1-14 & 43.20 & 26.42 & 4.27 & 0.03 \\
ADFI (g) & & & & \\
d 1-7 & 28.03 & 21.46 & 2.12 & 0.04 \\
d 8-14 & 92.80 & 48.66 & 6.33 & 0.01 \\
d 1-14 & 61.62 & 34.98 & 8.74 & 0.03 \\
FCR & & & & \\
d 1-7 & 1.21 & 1.35 & 0.02 & 0.02 \\
d 8-14 & 1.46 & 1.31 & 0.03 & 0.04 \\
d 1-14 & 1.43 & 1.32 & 0.02 & 0.03 \\
Mortality (\%) & & & & \\
d 1-7 & 0.00 & 0.00 & 0.00 & 0.89 \\
d 8-14 & 0.00 & 5.80 & 1.35 & $<0.01$ \\
d 1-14 & 0.00 & 5.80 & 1.36 & $<0.01$ \\
\hline
\end{tabular}

$\mathrm{AFB}_{1}$, aflatoxin $B_{1} ; S E M$, standard error of the means; $B W$, body weight; $A D G$, average daily gain; $A D F I$, average daily feed intake; $F C R$, feed conversion ratio.

${ }^{1)}$ Means represent 22 pens of ducks with 16 birds per pen ( $n=22 /$ group).

${ }^{2)} \mathrm{CON}$, basal diet; $\mathrm{AFB}_{1}$, basal diet containing 100\% contaminated corn.

${ }^{3)}$ The $A F B_{1}$ fed group contained $124.35 \mu \mathrm{g} / \mathrm{kg}$ from $\mathrm{d} 1$ to 14 .

\section{Growth performance}

The detrimental effects of $\mathrm{AFB}_{1}$ on growth performance may be due to anorexia, listlessness, impaired liver function, and inhibition of protein synthesis and lipogenesis [22,23]. As expected, the $\mathrm{ADG}$ and $\mathrm{ADFI}$ was reduced by $\mathrm{AFB}_{1}(124.35 \mu \mathrm{g} / \mathrm{kg})$ in the current study, which was in agreement with a study that reported that the growth and feed intake decreased by naturally contaminated $\mathrm{AFB}_{1}$ diets $(120.02 \mu \mathrm{g} / \mathrm{kg})$ during d 0 to 14 in Cherry valley ducklings [10]. Similar findings in ducks were observed by other

Table 6. Effects of feeding corn naturally contaminated with $\mathrm{AFB}_{1}$ on apparent ileal digestible energy and nutrients digestibility in ducklings ${ }^{1)}$

\begin{tabular}{lcccr}
\hline Item (\%) & CON $^{2)}$ & AFB $_{1}{ }^{2), 3}$ & SEM & p-value \\
\hline $\begin{array}{l}\text { Energy } \\
\text { ADE }\end{array}$ & 78.17 & 74.33 & 0.98 & 0.04 \\
Nutrients & & & & \\
DM & 71.13 & 73.82 & 0.10 & $<0.01$ \\
EE & 93.23 & 92.15 & 0.20 & 0.09 \\
N & 83.37 & 85.58 & 0.72 & 0.03 \\
AA & & & & \\
Lys & 87.21 & 90.14 & 0.13 & $<0.01$ \\
His & 87.76 & 90.14 & 0.19 & $<0.01$ \\
Arg & 90.55 & 92.69 & 0.20 & $<0.01$ \\
Thr & 76.73 & 81.16 & 0.25 & $<0.01$ \\
Met & 87.87 & 90.92 & 0.52 & 0.01 \\
lle & 81.55 & 86.19 & 0.58 & $<0.01$ \\
Leu & 70.96 & 77.63 & 0.53 & $<0.01$ \\
Phe & 78.67 & 85.23 & 1.63 & 0.04 \\
Val & 82.79 & 86.58 & 0.19 & $<0.01$ \\
Asp & 81.24 & 84.20 & 0.22 & $<0.01$ \\
Ser & 80.54 & 84.87 & 0.31 & $<0.01$ \\
Glu & 88.65 & 91.36 & 0.21 & $<0.01$ \\
Gly & 77.68 & 82.43 & 0.28 & $<0.01$ \\
Ala & 85.66 & 87.83 & 0.28 & $<0.01$ \\
Cys & 83.17 & 85.66 & 0.54 & 0.01 \\
Pro & 84.31 & 86.07 & 0.29 & $<0.01$ \\
Total AA & 84.80 & 88.11 & 0.14 & $<0.01$ \\
\hline AFB & & & & \\
\hline
\end{tabular}

$A F B_{1}$, aflatoxin $B_{1} ; S E M$, standard error of the means; $A D E$, apparent digestible energy; $D M$, dry matter; $E E$, ether extract; $A A$, amino acid.

${ }^{1)}$ Means represent 22 pens of ducks with 8 birds per pen ( $n=22 /$ group).

${ }^{2)} \mathrm{CON}$, basal diet; $\mathrm{AFB}_{1}$, basal diet containing $100 \%$ contaminated corn.

${ }^{3)}$ The $A F B_{1}$ fed group contained $124.35 \mu \mathrm{g} / \mathrm{kg}$ from d 1 to 14 .

Table 7. Effects of feeding corn naturally contaminated with $\mathrm{AFB}_{1}$ on serum hormones levels in ducklings"

\begin{tabular}{lcccc}
\hline Item $(\mathbf{p g} / \mathrm{mL})$ & $\mathrm{CON}^{2)}$ & AFB $_{1}{ }^{2), 3)}$ & SEM & p-value \\
\hline NPY & 175.82 & 172.19 & 9.08 & 0.64 \\
Ghrelin & 83.59 & 80.24 & 5.54 & 0.46 \\
Leptin & 6.81 & 8.36 & 0.30 & 0.03 \\
CCK-8 & 3.92 & 4.44 & 0.57 & 0.28 \\
Insulin & 16.89 & 16.59 & 1.34 & 0.78 \\
IGF-1 & 220.44 & 301.84 & 20.68 & 0.04 \\
\hline
\end{tabular}

$\mathrm{AFB}_{1}$, aflatoxin $\mathrm{B}_{1} ; \mathrm{SEM}$, standard error of the means; NPY, neuropeptide $\mathrm{Y}_{\text {; }} \mathrm{CCK}-8$, cholecystokinin-8; IGF-1, insulin-like growth factors -1.

${ }^{1)}$ Means represent 22 pens of ducks with 8 birds per pen ( $n=22 /$ group).

${ }^{2)} \mathrm{CON}$, basal diet; $\mathrm{AFB}_{1}$, basal diet containing 100\% contaminated corn.

${ }^{3)}$ The $A F B_{1}$ fed group contained $124.35 \mu \mathrm{g} / \mathrm{kg}$ from d 1 to 14 . 
Table 8. Effects of feeding corn naturally contaminated with $\mathrm{AFB}_{1}$ on average relative expression of jejunum $\mathrm{Na}^{+}, \mathrm{K}^{+}$-ATPase gene in ducklings ${ }^{1)}$

\begin{tabular}{|c|c|c|c|c|}
\hline Item & $\mathrm{CON}^{2)}$ & $\mathrm{AFB}_{1}{ }^{2), 3)}$ & SEM & p-value \\
\hline $\mathrm{Na}^{+}, \mathrm{K}^{+}$-ATPase & 0.037 & 0.045 & 0.005 & 0.35 \\
\hline
\end{tabular}

studies [6-8] with purified $\mathrm{AFB}_{1}$ (from 40 to $200 \mu \mathrm{g} / \mathrm{kg}$ ). Consistently, a recent study indicated that purified $\mathrm{AFB}_{1}(200 \mu \mathrm{g} / \mathrm{kg})$ decreased the $14 \mathrm{~d}$ body weight gain and ADFI of Pekin ducklings by approximately $33 \%$ [11]. Interestingly, FCR was reduced by $10 \%$ and $8 \%$ during $\mathrm{d} 8$ to 14 and 1 to 14 , while increased by $11 \%$ during $\mathrm{d} 1$ to 7 in the study herein. In contrast, others observed that FCR was improved by purified $\mathrm{AFB}_{1}$ ( 40 to $200 \mu \mathrm{g} / \mathrm{kg}$ ) in ducks [6-8,24]. However, FCR was not affected by semi-purified $\mathrm{AFB}_{1}(200 \mu \mathrm{g} / \mathrm{kg})$ in Pekin ducklings [11] and naturally contaminated $\mathrm{AFB}_{1}$ (from 120.02 to $128.7 \mu \mathrm{g} / \mathrm{kg}$ ) in Cherry valley ducklings $[9,10]$ from $\mathrm{d} 0$ to 14 . This inconsistency in FCR was also observed in broilers. FCR was decreased in broilers fed naturally contaminated $\mathrm{AFB}_{1}$ diets $(44.5 \mu \mathrm{g} / \mathrm{kg})$ [25], whereas FCR was improved by purified $\mathrm{AFB}_{1}(1,500 \mu \mathrm{g} / \mathrm{kg})$ [26]. This inconsistence may be due to $\mathrm{AFB}_{1}$ origins (corn naturally contaminated or inoculated with purified mycotoxins), dosage and speciesspecificity. The lack of $\mathrm{AFB}_{1}$ effect on FCR was attributed to the ducks maturity [11]. The decrease in the rate of excreta to pass through the digestive tract in ducks may lead to the reduction in FCR [10], which was supported by some studies that reported the fusarium toxin decreased the excreta emptying rate in growing pigs and broilers, respectively $[27,28]$. Therefore, the reduction in ADG may be due to the decreased ADFI, whereas the reduced ADFI may be attributed to the decrease in excreta passage rate, which was supported by the decreased FCR in this study. All the deaths caused by $\mathrm{AFB}_{1}$ happened in the second week because of the chronic and accumulated mycotoxicosis [9]. Nevertheless, more research is needed to evaluate the influence of naturally contaminated $\mathrm{AFB}_{1}$ diets on poultry because some reaction in enzyme activities and cell wall degradation may take place.

\section{Apparent ileal digestibility}

Several studies have revealed the $\mathrm{AFB}_{1}$ effect on the gastro-intestinal tract $[10,11]$. It was reported the biotransformation of $\mathrm{AFB}_{1}$ to the toxic AFBO was also occurred in the intestinal tract [12]. Therefore, the digestion and absorption in gastro-intestinal tract may be affected by $\mathrm{AFB}_{1}$. However, there was limited literature about the nutrient digestibility in ducks. Reduced apparent ileal digestible energy $(\mathrm{ADE})$ in birds fed $\mathrm{AFB}_{1}$ diets was observed in this study, which was in agreement with several studies in Pekin ducklings $(200 \mu \mathrm{g} / \mathrm{kg})$ from d 0 to 14 [11] and in broilers $(2,000$ $\mu \mathrm{g} / \mathrm{kg})$, respectively [29]. Purified $\mathrm{AFB}_{1}(200 \mu \mathrm{g} / \mathrm{kg})$ did not affect apparent ileal DM and $\mathrm{N}$ digestibility in Pekin ducklings [11]. Re- duced $\mathrm{N}$ digestibility upon $\mathrm{AFB}_{1}$ exposure $(200 \mu \mathrm{g} / \mathrm{kg})$ in Cherry Valley ducks was observed [8]. On the contrary, apparent ileal $\mathrm{DM}, \mathrm{N}$, and AA digestibility was improved by $\mathrm{AFB}_{1}$ in the herein study. A study indicated that improved proenzymes were released from the injured pancreas in response to $\mathrm{AFB}_{1}(200 \mu \mathrm{g} / \mathrm{kg})$ in Cherry Valley ducks [8]. Meanwhile, improved pancreatic amylase and lipase activity was observed in Pekin ducklings given purified $\mathrm{AFB}_{1}(200 \mu \mathrm{g} / \mathrm{kg})$ [11]. The authors also proposed that the compensatory effect of the birds in response to decreased ADFI to meet their nutrient need might be a possible reason, yet the improved enzyme activities was not enough to restore the damage to growth performance from $\mathrm{AFB}_{1}$. Notwithstanding this, the reason for the increased apparent ileal DM, N, and AA digestibility requires further research to determine whether it was due to the improved enzymes or other factors.

\section{Serum hormones levels and relative gene expression of $\mathrm{Na}^{+}, \mathrm{K}^{+}$-ATPase}

Because of the dramatic reduction in $\mathrm{ADFI}$ by $\mathrm{AFB}_{1}$, it was hypothesized that the adverse effects of $\mathrm{AFB}_{1}$ on ducks were correlated to nutrient absorption transporter and several hormones involved in ingestion and digestion. Therefore, this was an important issue in this study. Liver is the primary target organ of $\mathrm{AFB}_{1}$, which was demonstrated by other researchers $[9,30]$ who observed hepatic physical change and impaired hepatic function. Leptin (a satiety hormone), is mainly produced in the adipocytes of white adipose tissue, and can regulate fat stores through depressed appetite and increased energy consumption [31]. Furthermore, fatty liver can be caused by $\mathrm{AFB}_{1}$ [32]. Leptin was increased by $\mathrm{AFB}_{1}$ in this study. Accordingly, it was supposed that leptin showed a compensatory increase to inhibit adipose synthesis and promote adipose lipolysis caused by fatty liver in response to $\mathrm{AFB}_{1}$. Although IGF-1, produced mainly in the liver, was a primary mediator of the effects of growth hormone and had growth-promoting effects, it is an important cytokine of the liver inflammation and fibrosis. Dietary $\mathrm{AFB}_{1}$ had no effect on ghrelin, NPY and CCK-8 in the current study. Ghrelin (hunger hormone) and NPY were opposed by the action of leptin, which can increase appetite. CCK-8, synthesized and released by enteroendocrine cells in the mucosal lining of the small intestine (mostly in the duodenum and jejunum), suppressed hunger and feed intake through reduced rate of gastric emptying [33].

The $\mathrm{Na}^{+}, \mathrm{K}^{+}$-ATPase is a solute pump that pumps sodium out of cells while pumping potassium into cells, both against their concentration gradients. The $\mathrm{Na}^{+}, \mathrm{K}^{+}$-ATPase helps maintain resting potential, effects transport, and regulates cellular volume [34]. Particularly, it is used to transport most nutrients in the intestinal tract, which can reflect the absorption of nutrients [35]. The $\mathrm{AFB}_{1}$ may affect the tight junction proteins, which were the major constituent of gut barrier for the latter function, thus any damage to these proteins' synthesis and activities may result in an increase of permeability of the selective gut barrier $[11,12]$. 
The relative expression of jejunum $\mathrm{Na}^{+}, \mathrm{K}^{+}$-ATPase gene was numerically increased by $22 \%$ in ducklings fed $\mathrm{AFB}_{1}$ diets in the herein study. Although the $\mathrm{AFB}_{1}$ effect on the relative expression of jejunum $\mathrm{Na}^{+}, \mathrm{K}^{+}$-ATPase gene was not significant, the large increase in number may partially mirror the gut permeability to some degree. Previous studies indicated that increased gut permeability may also facilitate the absorption of any presented mycotoxins $[11,12]$.

It was hypothesized that the mechanism for the depressed feed intake by $\mathrm{AFB}_{1}$ may be as follows: decreased ADFI may be due to the improved leptin, which inhibited appetite and adipose synthesis caused by fatty liver. In addition, the increase in nutrient digestibility and feed efficiency may be due to the reduced rate of gastric emptying and improved enzyme activities.

\section{CONCLUSION}

Based on the above findings and discussions, feeding naturally contaminated corn diets $(124.35 \mu \mathrm{g} / \mathrm{kg})$ depressed the growth performance in ducklings through the reduction of ADFI, which may partially be due to the increased leptin. The decreased FCR originated from reduced ADG which further decreased ADFI.

\section{CONFLICT OF INTEREST}

We certify that there is no conflict of interest with any financial organization regarding the material discussed in the manuscript.

\section{ACKNOWLEDGMENTS}

This work was supported by grants from the State Key Research and Development Program in 13th Five-Year Plan (2016YFC 0502601) and China Agriculture Research System (CARS-40-30).

\section{REFERENCES}

1. Yunus AW, Razzazi-Fazeli E, Bohm J. Aflatoxin B1 in affecting broiler's performance, immunity, and gastrointesntinal tract: a review of history and contemporary issues. Toxins 2011;3:566-90.

2. FAO. Selected Indicators of Food and Agriculture Development in Asia-Pacific Region 1999-2002. Bangkok, Thailand: Regional Office for Asia and the Pacific, Food and Agriculture Organization of the United Nations, 2003.

3. Muller RD, Carlson CW, Semeiuk G, Harshfield GS. The response to chicks, ducklings, goslings, pheasants and poults to graded levels of aflatoxin. Poult Sci 1970;49:1346-50.

4. Iheshiulor OOM, Esonu BO, Chuwuka OK, et al. Effects of mycotoxins in animal nutrition: a review. Asian J Anim Sci 2006;5:19-33.

5. Ao ZG, Chen DW. Recent trends of mycotoxin contamination in animal feeds and raw materials in China. China Anim Husb Vet Med 2008;35:152-6.

6. Cheng YH, Shen TF, Pang VF, Chen BJ. Effects of aflatoxin and caro- tenoids on growth performance and immune response in mule duckling. Comp Biochem Physiol Part C Toxicol Pharmacol 2001;128: 19-26.

7. Bintvihok A, Davitiyananda D. Aflatoxins and their metabolite residues in chicken tissues from 5 parts (10 provinces) of Thailand. Thai J Health Res 2002;16:37-50.

8. Han XY, Huang QC, Li WF, Jiang JF, Xu ZR. Changes in growth performance, digestive enzyme activities and nutrient digestibility of cherry valley ducks in response to aflatoxin $\mathrm{B}_{1}$ level. Livest Sci 2008; 119:216-20.

9. He J, Zhang KY, Chen DW, et al. Effects of maize naturally contaminated with aflatoxin $\mathrm{B}_{1}$ on growth performance, blood profiles and hepatic histopathology in ducks. Livest Sci 2013;152: 192-9.

10. Feng GD, He J, Ao X, Chen DW. Effects of maize naturally contaminated with aflatoxin $B_{1}$ on growth performance, intestinal morphology, and digestive physiology in ducks. Poult Sci 2017;96:1948-55.

11. Chen X, Murdoch R, Zhang Q, Shafer DJ, Applegate TJ. Effects of dietary protein concentration on performance and nutrient digestibility in Pekin ducks during aflatoxicosis. Poult Sci 2016;95:834-41.

12. Sergent T, Ribonnet L, Kolosova A, et al. Molecular and cellular effects of food contaminantsand secondary plant components and their plausibleinteractions at the intestinal level. Food Chem Toxicol 2008; 46:813-41.

13. Sporn MB, Dingman CW, Phelps HL, Wogan GN. Aflatoxin $B_{1}$ : binding to DNA in vitro and alteration of RNA metabolism in vivo. Science 1966;151:1539-41.

14. Garvican L, Cajone F, Rees KR. The mechanism of action of aflatoxin $\mathrm{B}_{1}$ on protein synthesis; Observations on malignant, viral transformed and untransformed cells in culture. Chem Biol Interact 1973;7:39-50.

15. Grenier B, Applegate TJ. Modulation of intestinal functions following mycotoxin ingestion: meta-analysis of published experiments in animals. Toxins 2013;5:396-430.

16. National Research Council. Nutrient requirements of poultry. 9th revised. Washington, DC: National Academy Press; 1994.

17. AOAC. Official methods of analysis of AOAC International.17th ed. Gaithersburg, MD: AOAC International; 2000.

18. AOAC. Official methods of analysis of AOAC International. 17th ed. Gaithersburg, MD: AOAC International; 1995.

19. Gal-Garber O, Mabjeesh SJ, Sklan D, Uni Z. Nutrient transport in the small intestine: $\mathrm{Na}^{+}, \mathrm{K}^{+}$-ATPase expression and activity in the small intestine of the chicken as influenced by dietary sodium. Poult Sci 2003;82:1127-33.

20. Pfaffl MW. A new mathematical model for relative quantification in real-time PR-PCR. Nucleic Acids Res 2001;29:2002-7.

21. European Commission. Commission recommendation of 17 August 2006 on the presence of deoxynivalenol, zearalenone, ochratoxin A, T-2 and HT-2 and fumonisins in products intended for animal feeding. Off J Eur Union L229:7-9.

22. Oguz H, Kurtoglu V, Coskun B. Preventive efficacy of clinoptilolite in broilers during chronic aflatoxin (50 and $100 \mathrm{ppb}$ ) exposure. Res Vet Sci 2000;69:197-201.

23. Ortatatli M, Oğuz H. Ameliorative effects of dietary clinoptilolite on 
pathological changes in broiler chickens during aflatoxicosis. Res Vet Sci 2001;71:59-66.

24. Khajarern J, Khajarern S. Effect of fermkito (natural product of chitin, chitosan and chitosan oligosaccharide fermented with probiotics) to reduce the toxicity of aflatoxin and zearalenone in duck diets [Ph.D thesis]. Khon Kaen, Thailand: Khon Kaen University; 2001.

25. Resanovic R, Sinovec Z. Effects of limited feeding of aflatoxin $B_{1}$ contaminated feed on the performance of broilers. Mycotoxin Res 2006;22: 183-8.

26. Chen X, Naehrer K, Applegate TJ. Interactive effects of dietary protein concentration and aflatoxin $\mathrm{B} 1$ on performance, nutrient digestibility, and gut health in broiler chicks. Poult Sci 2016;95:1312-25.

27. Rotter BA, Thompson BK, Prelusky DB, et al. Response of growing swine to dietary exposure to pure fumonisinB1 during an eight-week period: growth and clinical parameters. Nat Toxins 1996;4:42-50.

28. Danicke S, Mattes S, Halle I. Effects of graded levels of fusarium toxincontaminated wheat and of a detoxifying agent in broiler diets on performance, nutrient digestibility and blood chemical parameters. Br Poult Sci 2003;44:113-26.
29. Verma J, Swain BK, Johri TS. Effect of various levels of aflatoxin and ochratoxin A and combinations thereof on protein and energy utilisation in broilers. J Sci Food Agric 2002;82:1412-7.

30. Ellakany HF, Abuakkada SS, Oda SS, El-Sayed YS. Influence of low levels of dietary aflatoxins on Eimeria tenella infections in broilers. Trop Anim Health Prod 2011;43:249-57.

31. Bartek J, Bartos J, Galuska J, et al. Expression of ob gene coding the production of the hormone leptin in hepatocytes of liver with steatosis. Biomed Pap Med Fac Univ Palacký Olomouc, Czech Repub 2001;145: 15-20.

32. Ortatatli M, Oğuz H, Hatipoğlu F, Karaman M. Evaluation of pathological changes in broilers during chronic aflatoxin (50 and $100 \mathrm{ppb})$ and clinoptilolite exposure. Res Vet Sci 2005;78:61-8.

33. Shillabeer G, Davison JS. Proglumide, a cholecystokinin antagonist, increases gastric emptying in rats. Am J Physiol 1987;252:R353-60.

34. Hall JE, Guyton AC. Textbook of medical physiology. St. Louis, MO, USA: Elsevier Saunders; 2006.

35. Sklan D, Noy Y. Hydrolysis and absorption in the small intestines of posthatch chicks. Poult Sci 2000;79:1306-10. 